\title{
The Food We Waste-Material and Ethical Issues in Geography
}

\author{
Walter Leimgruber \\ Department of Geosciences, Geography, University of Fribourg, CH-1700 Fribourg, Switzerland
}

\begin{abstract}
Global food supply has for a long time been regarded as only a problem of food production. Since the turn of the century, however, other aspects have entered the debate, such as improving food quality, changing eating habits and avoiding food waste. The latter topic has become the subject of attention for the past 10 years and the interest in it has steadily grown. This paper focuses on food waste within the overall context. Apart from the purely quantitative (material) aspects, it draws our attention to the immaterial side of waste, which has to do with our value system. It hopes to sharpen our minds towards a responsible way of dealing with resources.
\end{abstract}

Key words: Food, waste, values, attitudes.

\section{Problems with and Concepts of Waste}

What is waste, who produces waste, why is waste an issue and what are its geographical implications? The late 20th century has seen heaps of waste being piled up, collected, deposited in landfills or incinerated, either in the countries of "production" or exported to countries of the South. Waste has developed into a major predicament because of the many problems associated with it: area needed for landfills, risks to groundwater, air pollution from incinerators, toxic substances in incinerator cinders, the difficulty of finding final dumps for cinders without harm to the environment and human health, and the non-consideration for the health of people who live close to waste disposal facilities. We can consider waste from two different perspectives.

From our anthropocentric viewpoint, waste is material (solid, liquid and gaseous), which is no longer wanted or cannot be used any more [1]. Resulting from

Corresponding author: Walter Leimgruber, Ph.D., professor, research fields: boundaries and transborder relations, marginality and marginal regions. E-mail: walter.leimgruber@unifr.ch.

This paper was initially prepared in 2011. The present version is updated following recent data available. The update does not change the general statements. production processes and consumption, it is considered a burden to society and has to disappear (out of sight and out of mind). Solid waste can be deposited or incinerated, liquid waste is discharged or seeps into the hydrosphere, and gaseous waste pollutes the air we breathe. Since nobody wants all our refuse, humans have developed the "not in my back yard (NIMBY)" attitude [2]. Uncontrolled discharges in forests, riverbeds or into the sea are the result. Social, economic and environmental costs are ignored.

From a systemic perspective, on the other hand, waste are materials, which are discarded from a process because they are no longer needed or cannot be processed any further, but have to be integrated back into the system. Every system produces waste. Nature has developed a number of strategies to get rid of "dead matter": scavengers do away with carcasses and detritus, bacteria transform organic matter, metal reacts with oxygen, weathering and related processes reduce rocks to boulders and eventually sand. Nature does not produce "waste” as we define it, but converts inert material into new matter in an endless cycle of matter [3].

Throughout history, all societies have produced waste according to their respective technological 
development [4]. Waste of pre-industrial societies sooner or later returned into the system or did at least not harm the ecosystem. Archaeologists examine waste dumps, which mirror the ways of life and technology. The raw material, however, always came straight from nature and could return to it after decaying.

New materials have been developed since the industrial revolution and they have become increasingly resistant to natural degradation. In particular, the chemical processes has produced harmful substances, which nature cannot (or can hardly) deal with, may stay for a long time around and accumulate in the ecosystem. It may be a matter of time; probably all waste will degrade if we allow a sufficiently long period (most time being probably needed for nuclear waste), but will this suffice to save future generations from the dangerous consequences of today's waste production?

From a differentiated perspective, man-made waste is a complex collection of materials that are either degradable or not (Fig. 1). They are remains of transformative processes in all sectors of the economy: leftovers that can be reused (chaff, wood chips, metal plate residues after cutting or punching), faulty products due to mistakes during production (to be dismantled and/or repaired), exhaust gases, waste water after production processes, objects that can no longer be repaired (worn shoes), old-fashioned objects that cannot be used any more because of technological development (floppy discs, video tapes), rotten and mouldy food, etc.. Plastics are a particularly dangerous category of waste, although their reuse or responsible evacuation has increased in the past few years, at least in Europe [5].

But, waste is not just physical material and also has an immaterial side. Waste is part of the product cycle. At the outset, there are finite and renewable resources, which are transformed into consumer products. Consumers take decisions to buy and use the products, which they judge important for their life and which they will eventually discard. Resources and energy are being consumed all along the way. And in the end, the problem of disposing the waste has to be solved. Waste is part of an intricate cycle (Fig. 2). Every element and all flows have spatial manifestations, and this makes waste a topic for geographical research.

Waste is not the same to everyone. Certain items that are discarded by some people, may be perceived as having value by others. The idea that waste can in most cases be seen as a resource has appeared during World War II when resources were scarce because of trade limitations. People were asked to use raw materials sparingly and collect valuable items (such as light bulbs, electric wires, aluminium foils of chocolate wrappings) to recover as much material as possible. After 1950, the advent of the economic boom changed it. In an epoch of galloping demand and in the years of surplus of almost everything, anything being judged of no more value was simply thrown away-the one-way-society was born, at least in the North. This attitude also entered the field of nutrition.

This paper deals with a type of waste that is particularly significant from an ethical point of view. The debate around world hunger and the challenge to

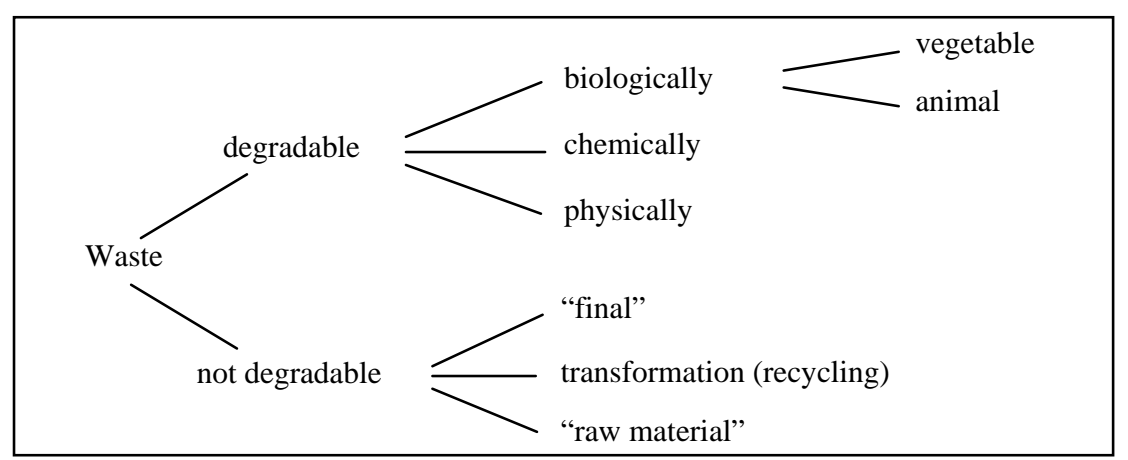

Fig. 1 A typology of waste (own elaboration). 


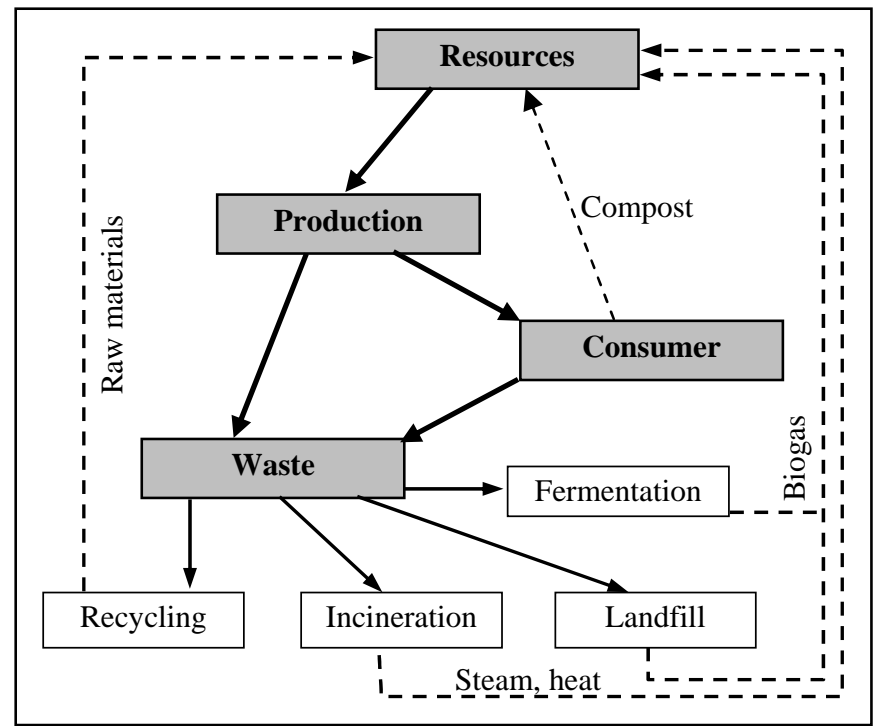

Fig. 2 A simplified waste cycle (own elaboration).

\begin{tabular}{|c|c|c|}
\hline Producers & Industry, transport & Consumers \\
\hline $\begin{array}{l}\text { Part of harvest cannot be collected } \\
\text { by mechanical device }\end{array}$ & Insufficient production capacity & $\begin{array}{l}\text { Cooking habits (too much, no } \\
\text { interest in leftovers) }\end{array}$ \\
\hline $\begin{array}{l}\text { Larger harvests than expected, not } \\
\text { all goods can be sold or given away }\end{array}$ & $\begin{array}{l}\text { Quality standards, health } \\
\text { regulations }\end{array}$ & No adequate storage facility \\
\hline $\begin{array}{l}\text { Price collapse, sale is uneconomic } \\
\text { (revenue does not cover the cost) }\end{array}$ & Transport damage & Shopping habits (planning) \\
\hline $\begin{array}{l}\text { Storage capacities (storage volume } \\
\text { available; possibility of the } \\
\text { individual product) }\end{array}$ & Seasonality of product & $\begin{array}{c}\text { Taking the dates on the package too } \\
\text { narrowly }\end{array}$ \\
\hline Uncertainty of market & Overproduction & Change of taste \\
\hline
\end{tabular}

Fig. 3 Food waste along the food chain (own elaboration).

feed a growing population on earth, makes food waste must not be neglected. As the paper will show, we are confronted with a problem of attitude. In the countries of the North, people have become used to get enough (or even too much) to eat, so that they have lost the respect for food and take it for granted. However, to throw away food is morally objectionable, in particular when it is still edible. In June 2011, thousands of tons of cucumber were discarded simply because of the unconfirmed rumour that they were at the heart of an epidemic caused by the Enterohemorrhagic Escherichia coli (EHEC) bacteria [6]. Common sense had given way to panic-it is marginalization in the mind.

\section{Food Waste}

Food waste is often blamed on the consumer alone. But in reality, it may occur all along the food chain, from the producers via the industry and transport to the consumer (Fig. 3). However, it is usually the latter because people often pay least attention. Farmers can return their waste into the natural cycle (ploughing, composting), feed it to animals and ferment or distil it; the industry can reuse the raw materials contained in surplus or faulty products. Consumers, on the other hand, have to rethink their eating, shopping and 
storing strategies. Composting food waste is an alternative, but not open to everybody. Again we are confronted with the material and the immaterial side of food waste.

This chapter comprises two sections. We shall first look at the quantitative aspects by using statistical material found in publications of the British Waste and Resources Action Programme (WRAP). The second section is devoted to the immaterial side of food waste, i.e., motivation, attitudes and the value system.

\subsection{The Material Issue}

Conforming to the above definition, food waste is food that is no longer needed and is discarded in some way. Whether this is morally justifiable will be discussed later, and here we look at its material side (state, type, quantity, cost). Food waste is highly differentiated. It can be raw, processed or cooked, or it may be inedible, the quantities may be important or negligible and the cost can be high or low. This in turn relates to people's social standing, education, income, lifestyle, attitude to food, etc.. It is not possible to totally separate these aspects from the purely material side.

It is difficult to obtain data on this particular type of waste, as it is absent from official statistics. Details can only be gathered through specific surveys, but their data are not internationally comparable because the methodology and the periods of collection are usually different. They study only waste that can be easily examined (waste bins or bags). Of course we do not know which and how much food waste individuals will put onto their own compost. Therefore, the two examples below cannot be generalized quantitatively, but the attitudes behind are similar.

The primary sources for this paper are the first reports published by the British Government's WRAP [7-9]. They are based on the detailed surveys of food waste and the interviews and content analysis of dustbins. For the 2007 research, a total of 2,939 interviews were held. The 2008 report drew on 2,715 interviews and 2,138 analyses of the dust bins of private households (restaurants, canteens or collective households such as hospitals, prisons, etc., were not included). The 2009 report, finally, used 319 diaries kept by respondents over $7 \mathrm{~d}$ and completed by two interviews (before and after). A second set of data comes from a diploma thesis elaborated in the late 1980s [10]. Additional information can be found in Hall et al. [11]. The WRAP conducted a second survey in 2012, updating its 2007 findings [12].

When Fleury undertook his study in the small town of Delémont (Canton of Jura, Switzerland), his theoretical basis was extremely narrow. His only inspiration was a book by a French geographer, Gouhier [13], who in 1972 pioneered the study of rudologie (from Latin rudus, refuse) - the science of studying waste [10]. Fleury was not only interested in the amount of waste people produced every week but also in the contents of the dustbins and the social background. To this end, he identified six categories of households, where he collected and analyzed the dustbins:

(1.1) 8 families of modest income in blocks of flats;

(1.2) 8 households of modest income in single family houses;

(2.1) 10 households of middle income in blocks of flats;

(2.2) 13 households of middle income in single family houses;

(3) 8 families living in high-standing single family houses;

(4) 12 households of retired people in blocks of flats.

He did not specifically look for food waste but classed the trash by material properties ${ }^{1}$. Food is found in his groups "vegetable waste" and "animal waste”. Fortunately, he selected three food items in the former group (vegetables, fruit, leftovers from

\footnotetext{
${ }^{1}$ Apart from vegetable and animal waste, he separated the waste by glass, metal, plastic, cellulose-type refuse, inert waste, composite and complex waste.
} 
meals), so that the two categories plus "bread remains" furnish a relatively complete picture. To obtain an accurate picture, he weighed the waste by category (Table 1).

Vegetable waste accounted for one-third of the contents of the waste bins and was a very important component of garden refuse, which accounted for $60 \%$ of all vegetable waste, and $28 \%$ of all waste in category 3 (high-standing housing with gardens). If we discount garden waste, it emerges that the most wasteful households were those of category 1.1 (families with modest incomes in blocks of flats), who do not produce compostable garden waste. Living in a block of flats meants that they had no garden for composting; "green waste" collection had not been introduced by the time of this survey. The social standing of families and their standard of housing appear as the most important criteria, when it comes to the production of waste, in particular of food waste.

The most comprehensive and detailed investigations on food waste have been undertaken by the British Government's WRAP, a major three-tier research programme [7-9, 12]. Whereas Fleury's 1989 study had occurred at a local scale and allowed for no generalizations, the WRAP project covered the whole of Britain with various natural regions and social and cultural diversity. The organization is not profit-oriented and founded in the year 2000 [7]; and its mission is "to accelerate the move to a sustainable resource-efficient economy” [14]. The fundamental idea behind WRAP'S activities is "the 'circular economy' model as a framework for strategic thinking” [14]. To achieve this goal, the organization has developed a number of initiatives aiming at creating enhanced awareness in the population. A remarkable one in the present context is the campaign “love food, hate waste." The annual report provides insight into the agency's current activities. In the accounts for 2009-2010, one can read, for example, that "scottish households throw out 570,000 tons of food and drink each year, more than two-thirds of which could have been consumed" [15]. This statement demonstrates either fear from food poisoning (from old food) or simple carelessness, when it comes to manage the food at home. This same campaign also shows success: “a six month love food hate waste campaign helped west Londoners cut their avoidable food waste by $14 \%$, save the boroughs over $£ 1.3$ million by reducing food waste disposal costs” [16].

The three reports from 2007-2009 used different thematic approaches. The first publication investigated into people's perceptions of food waste [8], the second contains a detailed account of the types of food waste [7] and the third looks at food that is discarded via the sanitary system (washbasins, toilets) [9]. The latest survey was based on information from local authorities, and the analysis of food waste came from about 1,800 households and private kitchen diaries [12]. Not all results are comparable with the earlier reports, but they

Table 1 Food waste in Delémont, autumn 1989 (g/week/household).

\begin{tabular}{lllllll}
\hline Waste & Category 1.1 & Category 1.2 & Category 2.1 & Category 2.2 & Category 3 & Category 4 \\
\hline Vegetables & 2,172 & 547 & 869 & 930 & 1,818 & 546 \\
Fruit & 1,343 & 284 & 581 & 993 & 1,091 & 348 \\
Leftovers from meals & 1,273 & 383 & 1,021 & 668 & 397 & 153 \\
Bread remains & 177 & 178 & 316 & 11 & 95 & 201 \\
Animal waste & 402 & 249 & 142 & 146 & 309 & 131 \\
Total food waste & 5,367 & 1,641 & 2,929 & 2,748 & 3,710 & 1,379 \\
Garden waste & -- & 1,713 & -- & 957 & 5,096 & -- \\
\hline Total waste & 15,843 & 11,497 & 9,090 & 10,011 & 17,893 & 4,888 \\
\hline Food waste in \% of all waste & 33.9 & 14.3 & 32.2 & 27.4 & 20.7 & 28.2 \\
\hline
\end{tabular}

Source came from Ref. [10]. 
Table 2 Potatoes and bread: waste relative to purchase in the UK 2012.

\begin{tabular}{|c|c|c|c|c|}
\hline \multirow[t]{2}{*}{ Items } & \multicolumn{2}{|c|}{2007} & \multicolumn{2}{|c|}{2012} \\
\hline & tons & $\%$ & tons & $\%$ \\
\hline \multicolumn{5}{|l|}{ Potatoes } \\
\hline Total purchase & $1,700,000$ & 100 & $1,600,000$ & 100 \\
\hline Waste & 740,000 & 44 & 730,000 & 45 \\
\hline Avoidable waste & 280,000 & 16 & 320,000 & 20 \\
\hline \multicolumn{5}{|l|}{ Standard bread } \\
\hline Total purchase & $1,800,000$ & 100 & $1,600,000$ & 100 \\
\hline Waste & 650,000 & 37 & 460,000 & 28 \\
\hline Avoidable waste & 540,000 & 31 & 350,000 & 22 \\
\hline
\end{tabular}

Source came from Ref. [12].

Table 3 Bakery items thrown away, whole and still packed in the UK 2007.

\begin{tabular}{lllll}
\hline Type of food & \multicolumn{2}{c}{ Weight } & Cost \\
\cline { 2 - 5 } & Tons & $\%$ & 300 & $\%$ \\
\hline Bread items & 235,900 & 83.7 & 190 & 82.7 \\
Cakes, pastries & 39,300 & 14.0 & 30 & 11.5 \\
Biscuits and others & 6,700 & 2.3 & $* 520$ & 5.8 \\
Total bakery & 281,900 & 100 & 100 \\
\hline
\end{tabular}

Source came from Ref. [7]. *Due to a computing error, the figure in the source is $£ 490$.

will nevertheless be presented as far as possible. The detailed results cannot be reproduced in this paper, but a few select elements will be presented as an illustration.

The material aspect concerns the quantity and the types of food discarded by private households. Quantity is measured in weight and cost: people spend money to buy edibles which they eventually throw away. The figures are averages and do not apply to specific individual families. The following paragraphs concentrate on the 2008 and 2009 reports, leaving the 2007 one to the next chapter. The updates of 2012/13 are inserted wherever possible.

The most important finding of the 2007 survey was that UK households, who discarded about 6.7 million tons of food a year, which is close to $31 \%$ of all food purchased. Public bodies collect about $88 \%$ of this food waste, while the remainder either goes to private composts to feed animals or goes down the drain [7]. However, more than $60 \%$ of the food waste is avoidable, i.e., could still be eaten. Only 19\% are classed as unavoidable (tea bags, peels, animal carcasses) and have to be thrown away. In money terms, this quantity of food waste adds up to about $£ 12.8$ billion (£520/household) a year, which could certainly be spent more wisely. Due to a slightly different methodology, the 2012 figures are somewhat different: 7 million tons were discarded in one way or another, of which again $60 \%$ were avoidable [12], accounting for about $£ 470 /$ household. This figure is down $£ 50$ compared to 2007, but it consumes still $14 \%$ of the average weekly shopping budget.

Potatoes and standard bread were the most important avoidable food items thrown out (Table 2). There has been a slight decrease in the case of avoidable waste of bread, whereas proportionally more potatoes were wasted in 2012 than in 2007.

About a quarter of all food waste recorded in 2007 was still in its original packaging when discarded. By way of example, let us just look at the bakery items that were found in the dustbins (Table 3). Unfortunately, the 2012 survey did not furnish the same details, neither for the bakery items nor for all food waste.

For the author of this papers who has lived through World War II (albeit in a country without war, but 
with food rationing), the amount of bread thrown away is alarming. The survey found 69 million loaves of bread alone (31.2 tons, worth $£ 50$ million), to say nothing of bread slices, bread rolls, croissants and others. Bread is, in western culture, an important food item, and to throw it away comes close to a sacrilege.

In all, more than 1.5 million tons of food were thrown away whole (mostly packed), for which the customers paid more than $£ 3.3$ billion-money seems to be perceived as trash, too. This includes "more than 52,000 tons of unopened yoghurts and yoghurt drinks" [7]. The corresponding figure for food and drink discarded in 2012 was 4.2 million tons, worth $£ 12.5$ billion. However, the public has become aware of the problem, and certain types of waste have fallen since 2007. Yoghurt waste dropped from 1.7 million to 1.2 million items and bread from 37 million to 24 million slices [12], but this is still far too much.

Most of the 2007 food waste (51\%) had been either cooked (from fresh) or prepared (convenience food) at home. The report does not offer an explanation, but it is easy to imagine that cooking and eating were not well organized. In other words, people usually prepare too much food, but do not take into account that hunger is not always the same-certain persons in the household may not be very hungry or they may have eaten away from home, etc., so that leave their food on the plate. It may also look noble to leave some food on the plate. The figures suggest that leftovers are thrown away rather than re-used.

Major reasons for throwing away food are deficiencies in storage and management (this includes the plan for shopping and meal preparation). However, the reasons given by the interviewees sounded different: more than a third of the food thrown away was classed as "inedible" and one sixth as "left on the plate" and as "out of date”, respectively [12]. Whereas, "food left on the plate" is an objective category and the two others are to some extent subjective judgements. We shall discuss this dimension below.

A last problem remains: why do people dispose of food waste via the sanitary system? It may look understandable for all kind of liquids (drinks, soups, sauces), but is rather strange when it comes to meals, staple foods, meat and fish, or vegetables. In all, it was estimated that about 1.8 million tons went down the drain annually, of which one million is solid and only 0.8 million tons liquid [9]. The bulk of the solid waste are leftovers on plates, some of which may well go down the sink during washing up. However, the report cannot provide an answer to the question which part of the sanitary system (sink, toilet or outside drains) had been preferably used. At any rate, such food remains to pose additional problems to the sewage works. "Food waste in particular increases the level of suspended solids in the sewerage, which results in greater quantities of sewage sludge.” [9]. Composting would obviously be the least problematic solution.

\subsection{The Immaterial Side}

Waste is not only a material category that can be measured in tons and money terms. As has been said in the introduction, some people will consider waste as the end of a product cycle whereas others attribute it to material value. The idea that waste is also a raw material that can be used again, is not new, but it seems to have been forgotten during the economic boom years after 1960 . The waste separation and recycling philosophy of the late 20th century indicates a change of attitude towards reconsidering our values [3].

Every human activity is directed by our value system. All our actions originate in our minds, therefore food waste is not only an affair of disposal technologies but also of psychology. Values are the guiding principles that underlie our decisions and have an influence on the consequences (environmental, social, cultural) once they have been transformed into actions. Values are a spiritual complement to the psychological types identified by Jung [17]. They are extremes on a continuum, i.e., every individual (and 


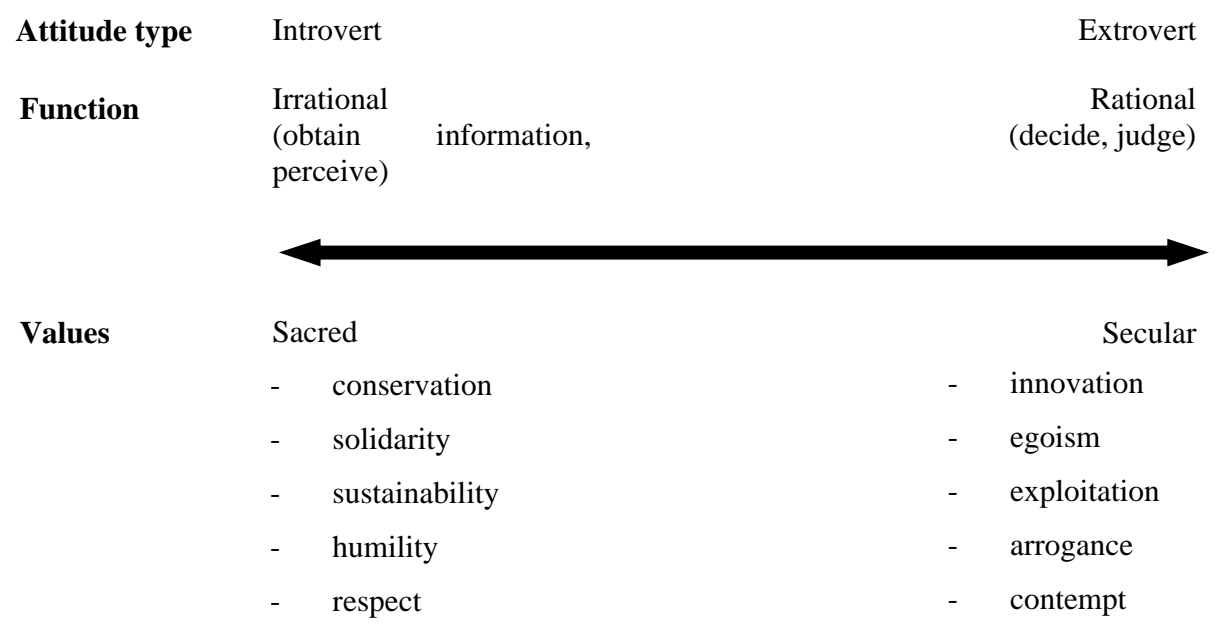

Fig. 4 The continuum of psychological types (above) and values (below).

Source from Refs. [17, 18].

every society by extension) can be classed somewhere along it (Fig. 4). The endpoints of extreme types and values are the exception rather than the rule.

The left side represents preservation, closeness, whereas the right side favours innovation and openness. Although the model looks static, it must be emphasized that values evolve over time, because they follow the adaptations, which humans have to make to the dynamics of life [19, 20]. Every society and culture has its own value system and therefore its own value dynamics.

This model proposes two major types of decision-makers: on the one hand, the extrovert type - the innovators who are outward oriented and seek to overturn what has been before and create something new (or at least different); on the other hand, the introvert type-the preservers who is inward oriented and oppose to any change and want to keep things as they are. The former acts are according to secular and the latter to sacred values. Inglehart and Welzel [21] use the denomination of secular-rational and traditional values. The two terms chosen for the values, are not religious notions but "general spiritual terms, referring to specific attitudes and modes of acting” [18]. Throughout human history, innovation has been a major driving force, but the industrial revolution introduced a major change: man began totransform nature to a degree hitherto unknown and the current environmental problems are the consequence of a radical value shift towards the secular extreme. On the other hand, there have always been limiting forces, even if during human history secular values became increasingly prominent.

With respect to our topic, thoughtlessly discarding food which could still be eaten, is a clear indication for a dominant secular value pattern. In fact, this applies to almost all waste produced by the postindustrial society. The idea that old objects are worthless (even if they still function perfectly) and have to be thrown away, mirrors the philosophy of the manufacturers who want to increase their sales by constant innovation (in design, colour and function of objects) and the creation of new needs and fashions. In the same line of thought, it is the idea that leftovers from cooking have to be disposed of, because they are "old" and can no longer be consumed; and food is "old" if it is one day beyond the date printed on the package. There seems to be a profound lack of common sense in our over-regulated present-day society.

Values and attitudes are the basis to such ways of thinking, but food waste is also a matter of personal perception. If education and information influence or 
condition consumers get to a large extent, they can no longer see and judge clearly, but will simply see what others want them to see. Advertising is extremely powerful in this respect. In the field of nutrition, the introduction of dates on food packages ("best before" or "to be sold by") was meant to be of help to the consumer. However, this measure also raised the fear that after the date printed on the package the food would be bad, rotten, inedible-a danger to health. However, there is obviously an error of communication. The dates do not refer to food safety but rather to optimum quality or flavour [22]. The reference dates printed on the packages are there to ensure that the shops do not sell old and decaying food. There is no immediate danger. If properly stored, a product can be consumed after the "use by" date printed on the package, but proper storage and management of the stock are essential. A test by the alliance of Swiss consumer organizations has revealed that even perishables, like milk, yoghurts, cooked ham and desserts, etc., can be consumed up to four weeks beyond the date [23].

The British 2006 survey showed that many people were initially not conscious that they were wasting food, but became aware of it during the interviews [8]. The chief reason given ( $60 \%$ of all answers) was the date printed on the packages. Besides, more than half of the respondents admitted that they had cooked too much and that food nobody wanted any more were left. This is not always their fault. Portion sizes from supermarkets are not geared to specific family sizes, e.g., single person households. The authors of the report emphasize that the presence of people who have lived through World War II helps to explain the initial reaction to the question. They had been taught to respect for food and use leftovers for further meals; hence their perception was that they produced little food waste [8].

Food waste is also a sign that many people still have too much money. At least this is a conclusion that we can draw from the fact that the major part of discarded food (almost 80\%) by its monetary value is a consequence of bad food plan at home (Fig. 5).

\section{Prevention: Teaching, Waste Policies, New Thinking}

Food waste is not the principal reason for world hunger but an issue that has to be dealt with by the "North". The current food crisis in the "South" cannot be solved, if the "North" considers reducing food waste as the ultimate remedy. No child in Africa will receive more to eat if I do not waste food. The issue is much more complex and far-reaching, and it has to do with the attitudes towards food. It is not just a technical issue [24] but an ethical and moral one-a point made by the FAO ten years ago already [25].

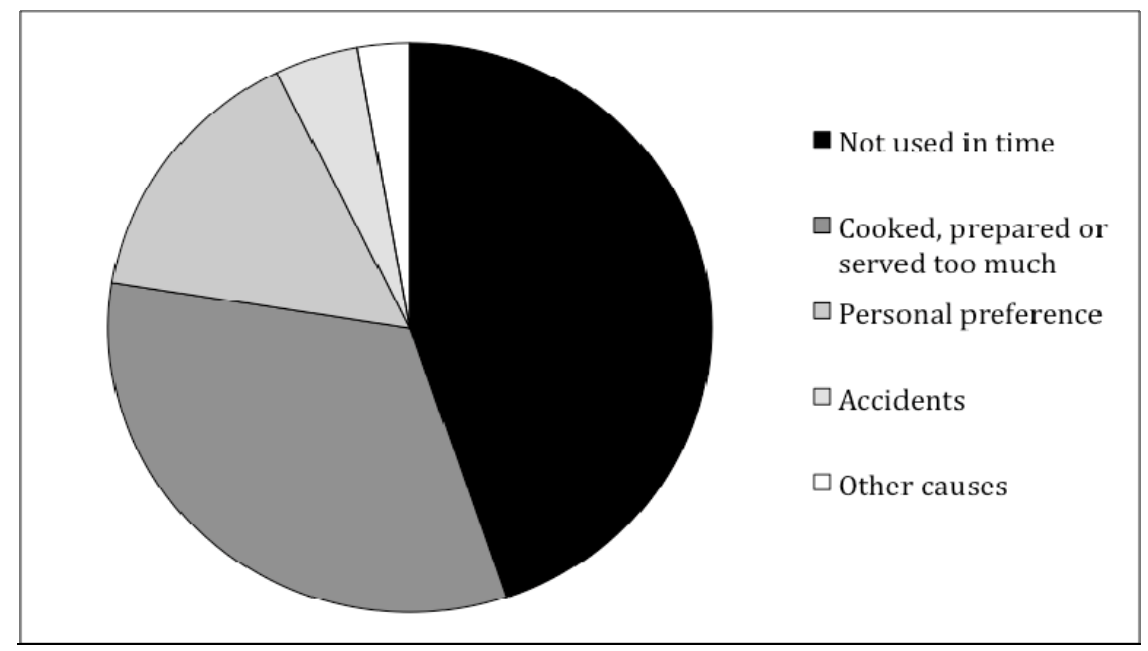

Fig. 5 Reasons for wasting food, 2012.

Source from Ref. [12]. 
For a majority of people on Earth, food (including water) means nutrition, energy and the essential means for survival. They will work hard, and in emergencies, also beg (and even steal) in order to secure minimum rations for their livelihood. A large minority, on the other hand, considers food as a commodity to be bought and sold on the market and a means to make profit. This attitude is also supported by governments through subsidies given to farmers to increase their competitiveness on the international market and by free-trade agreements which facilitate the entry of cheap goods, thereby destroying local markets and reducing local farmers' possibilities for cultivation. Defenders of food sovereignty fight against such practices and fight for better conditions [26].

There are a number of ways to prevent excessive throwing away of food, and both the individual consumers and the society are facing this challenge. We can list the following proposals:

Education: teaching starts at home and continues through school. Parents and teachers have to teach children that food is essential to survival and therefore has to be respected. To install a deeper sense for this, schools can create vegetable gardens where the children experience the difficulties involved in growing food [27], but where also the respect for food can be taught. After all, "the children of today are the thinkers of tomorrow” [28], and they will thus be able to transmit their knowledge to their own children.

Composting: A certain amount of food waste will always be unavoidable. Instead of discarding it with the general waste, it can be composted. Composts are ideal for private households with gardens (single family housing), but they could also be organized on a collective basis in blocks of flats-they could be a means to promote community spirit. Small-scale composting is possible on the balcony where no garden is available. Local or regional authorities can provide compost services as part of waste collection. Such large-scale collections of organic waste fulfil a double purpose: through fermentation, organic waste produces biogas that can be used to generate heat, electricity or biofuel (in this way part of the energy stored in the organic waste can be captured); and the remaining compost is a valuable fertilizer and humus for gardens. In this way, the carbon cycle can be closed and soil fertility can be enhanced for future generations [29].

Eco-efficiency: The idea of closing the cycle lies behind what may be the most radical of proposals - the “cradle to cradle” principle [3]. The authors are not satisfied with eco-efficiency (which is an economic minimizing strategy), but propose to continue to eco-effectiveness [30], which is related to ecological thinking and is an optimizing strategy. It means to see waste as a resource. Every single resource must therefore go back into the cycle. Composting food waste is just a small contribution to it.

Traditionally, food waste has often been used to feed animals, in particular the omnivore pigs. Farmers used to collect the leftovers from restaurants, canteens and other institutions, or specialised enterprises cooked them into a fodder soup and sold them to farmers. Recent cases of animal diseases (in particular bovine spongiform encephalopathy, BSE) have caused authorities to become more cautious in the interest of food safety. In 2001, the European Union prohibited the use of mammalian meat and bone meal in animal feed, because it was linked to the BSE crisis [31]. In the United States, food waste has to be boiled at $100{ }^{\circ} \mathrm{C}$ for 30 min before it can be fed to pigs [32]. In Japan, so-called eco-feed is produced from all kinds of food waste [33], but the prepared raw material has to be cooked at $70{ }^{\circ} \mathrm{C}$ for $30 \mathrm{~min}$ or at $80{ }^{\circ} \mathrm{C}$ for $3 \mathrm{~min}$. It is advised that "not to feed eco-feed containing mammal proteins to ruminants" [33]. This is logical (common sense!), because ruminants are herbivores.

Waste is not only a loss of materials but also a loss of energy: the grey energy behind a product (energy required to procure raw materials, for transportation, transformation or manufacturing, consumption and 
disposal) and the energy in our food. Therefore, to avoid waste as much as possible is also a way to save energy and costs. It must be done in an eco-effective way, which is based on a holistic outlook and long-term thinking. Saving energy is also a tool to improve the quality of the ecosystem.

In the US, the energy loss through food waste has been calculated as the equivalent of about 300 million barrels of oil per year or $4 \%$ of US oil consumption in 2003 [11], i.e., roughly one barrel per person. In energy terms, the evolution over the last 30 years of the 20th century has been catastrophic. In 1974, approximately $900 \mathrm{kcal} /$ person/day was wasted, whereas in 2003 Americans wasted 1,400 $\mathrm{kcal} /$ person/day or 150 trillion kcal/year [11]. This means that food waste has progressively increased from about 30\% of the available food supply in 1974 to almost $40 \%$ in recent years [11]. The figure of $1,400 \mathrm{kcal}$ is only little below the minimum daily caloric requirement of a man of $70 \mathrm{~kg}$ bodyweight (1,680 kcal). In other terms, with the food waste of two Americans, another person could survive!

\section{Further Issues}

Our reflections on food waste have started with its technical aspect, before discussing the spiritual background. In the end, we arrived at an overall perspective, where food waste is but one small element that can lead to a new assessment of economic activity. The material side has to be completed by an immaterial focus. Besides, there are at least three additional issues to be raised by the way of conclusion.

The food issue is part of the millennium development goals (MDG). Target 1C of goal 1 (halving the proportion of people suffering from hunger by 2015) is within reach but will most likely not be attained. The current evaluation shows that, despite considerable progress, the target will be missed by about $1.1 \%$ points $[34,35]$. Can the prevention of food waste in the "North" contribute towards this aim? The answer to this question has already been given, it is no. However, there is a complex chain showing that it might have an effect, not within five years, but in the longer run.

Let us develop just one chain of thought. The food link between the (overfed) "North" and the (undernourished) "South" is characterized by subsidies in the "North" for the production of cheap staple food that can be sold at low prices in the "South", thereby ruining local markets and creating disincentives for farmers to carry on subsistence farming. On the other hand, "Northern” investments in specific products (fruit, coffee, cocoa, oil palms, flowers etc.) deviate large surfaces in the "South" from food production, thus reducing the possible surfaces for subsistence and local market agriculture. Among the yoghurts thrown away every day in Britain (480 million unopened pots annually [7]), there are most likely also fruit yoghurt with exotic fruit added, fruit that was grown on surfaces where local food could have been grown. By a better management of food (in this case yoghurt), food waste could be avoided, with all the consequences at home (milk production, dairy cattle rearing etc.) and in the "South"-especially if exotic fruit were replaced by domestic fruits and berries.

Another element to be mentioned here is the loss of agricultural land across the world. This occurs through urbanization, land grabbing, monocultures and mining. Urbanization is a major process across the world. Land grabbing by companies and state agencies (domestic and foreign) deprive smallholders of land for subsistence and small-scale market farming [36, 37], to say nothing of consequences for the environment [38]. Monocultures to produce biofuels from maize or soybeans result in soil depletion. Applying synthetic fertilizers to improve the quality of soils brings temporary relief only, and yields will inevitably decline with increasing input [39]. Mining projects need not threaten farmland directly through mining but by requesting land for access roads, mining 
settlements, and surfaces for the deposit of waste material and (toxic) tailings [40]. The result of such concentrated assaults on farmland is: the less good quality agricultural land remains, the more difficult it will become to nourish the world population and not only reach but go beyond the MDG 1C.

Hunger is a violation of article $25 / 1$ of the Universal Declaration of Human Rights: "everyone has the right to a standard of living adequate for the health and well-being of himself and of his family, including food, clothing, housing and medical care and necessary social services, and the right to security in the event of unemployment, sickness, disability, widowhood, old age or other lack of livelihood in circumstances beyond his control”, a point taken up and reinforced in the 1966 International Covenant on Economic, Social and Cultural Rights (Article 11/1). Hunger is also a violation of article 3 ("everyone has the right to life, liberty and security of person"). Even if food waste in the "North" is not directly linked to hunger and malnutrition in the "South", we still participate in this violation. The overfed population of the "North" deprives the people in the "South" of necessary surfaces to grow foodstuffs, and it aggravates this situation by not paying respect to food.

A change of values is imperative, and it has to go beyond Inglehart [19] shift from materialist survival values (dictated by economic need) to post-materialist self-expression values (the wish for self-fulfilment). The surplus society has enabled us (the "North") to secure adequate living conditions in nutrition and material comfort, and we could concentrate on goods and services that were not essential for survival but can be classed as "luxury". The price we pay for this is high: societies are increasingly drifting apart between haves and have-nots, and the ecosystem is under growing stress. The next value shift is imminent, and it has to lead us back to survival values driven by sheer ecological necessity [41]. This is not to advocate a return to a pre-industrial lifestyle, but to sharpen our consciousness and recognize the limitations of the ecosystem and our responsibility towards it. Food waste is but a small element in it, but it might be an easy starting-point.

\section{Conclusions}

To eradicate hunger on the global scale requires a variety of actions in order to achieve this goal, both material and immaterial. The seemingly simplest way to increase food production, is not the only solution, at least not in the way this is usually propagated. Farming practices must respect the environment and focus on the natural cycle of matter rather than on synthetic inputs. This is a question of attitude. The consumer side is also challenged: improving food management at home, better health care through appropriate nutrition and reducing food waste to the absolutely unavoidable can help to get more out of the food produced per person. This is also a question of attitude and consumers of the global North are invited to reflect on their value system.

\section{References}

[1] United Nations Statistics Division (UNSD). 1997. “Glossary of Environment Statistics.” Accessed February 04, 2015. unstats.un.org.

[2] Wolsink, M. 1994. "Entanglement of Interests and Motives: Assumptions behind the NIMBY-Theory on Facility Siting.” Urban Studies 31 (6): 851-66.

[3] Braungart, M., and McDonough, W. 2002. Cradle to Cradle: Remaking the Way We Make Things. New York: North Point Press.

[4] Silguy, C. 2009. History of Humans and Their Waste: From the Middle Ages to the Present. Paris: Le Cherche Midi. (in French)

[5] Plastics Europe. 2012. "Plastic Waste from Construction Sites in Europe: The Rate of Valorization Rises, but the Disparities between the Countries Persist.” Accessed February 04, 2015. http://www.plasticseurope.fr/centre-dinformations/salle-d e-presse/communiques-de-presse-2012/plasticseurope-pu blie-la-premiere-etude-comparative-sur-la-valorisation-de s-dechets-plastiques-du-batiment-en-europe.aspx. （in French)

[6] Paterson, T. 2011. "EU Sandwiched between Spain and Germany in Cucumber Wars.” The Independent, June 08, 2011. 
[7] Waste and Resources Action Programme (WRAP). 2008. "The Food We Waste." Accessed July 07, 2010. http://www.wrap.org.uk/retail/case_studies_research/repo rt_the_food_we.html.

[8] Waste and Resources Action Programme (WRAP). 2007. "We don't Waste Food! A Householder Survey." Accessed August 13, 2010. http://www.wrap.org.uk/downloads/We_don_t_waste_fo od_-_A_household_survey_mar_07.dcaab2c4.6397.pdf.

[9] Waste and Resources Action Programme (WRAP). 2009. "Down the Drain: Quantification and Exploration of Food and Drink Waste Disposed of to the Sewer by Households in the UK.” Accessed August 13, 2010. http://www.wrap.org.uk/downloads/Down_the_drain_-_r eport.e058d845.8049.pdf.

[10] Fleury, D. 1990. Household Waste-A Study of Waste and Recovered Materials from Households Differentiated according to Social, Economic, Urbanistic and Spatial Criteria within the Framework of an Urban Collectivity. Travail de diplôme de Géographie, Institut de Géographie, Université de Fribourg. (in French, unpublished)

[11] Hall, K. D., Guo, J., Dore, M., and Chow, C. C. 2009. "The Progressive Increase of Food Waste in America and Its Environmental Impact.” PLOS ONE 4 (11): e7940. Accessed December 25, 2014. http://www.plosone.org/article/info\%3Adoi\%2F10.1371 \%2Fjournal.pone.0007940.

[12] Waste and Resources Action Programme (WRAP). 2013. "Household Food and Drink Waste in the United Kingdom 2012.” Accessed December 25, 2014. http://www.wrap.org.uk/content/household-food-and-drin k-waste-uk-2012.

[13] Gouhier, J. 1987. The Waste Bin-A Social Mirror. Le Mans, France: GEDEG, Institut de Géographie, Université du Mans. (in French)

[14] Waste and Resources Action Programme (WRAP). 2015. “Our Vision.” Accessed February 05, 2015. http://www.wrap.org.uk/content/about-us.

[15] Waste and Resources Action Programme (WRAP). 2009. "Review of the Year 2009/10.” Accessed August 13, 2010. http://www.wrap.org.uk/downloads/Review_of_the_Year _20092010.e802bdf6.9492.pdf.

[16] Waste and Resources Action Programme (WRAP). 2014. "Waste \& Resources Action Programme Annual Report and Consolidated Accounts for the Year Ended 31 March 2014.” Accessed February 05, 2015. http://www.wrap.org.uk/sites/files/wrap/WRAP\%20Annu al\%20Report\%20and\%20Consolidated\%20Accounts\%20 March\%202014.pdf.

[17] Jung, C. G. 1921. Psychological Types. Zürich: Rascher Publisher. (in German)

[18] Leimgruber, W. 2004. Between Global and Local
Marginality and Marginal Regions in the Context of Globalization and Deregulation. Aldershot: Ashgate Publisher, 71.

[19] Inglehart, R. 2008. “Changing Values among Western Publics from 1970-2006.” West European Politics 31 (1-2): 130-46.

[20] Welzel, C., and Inglehart, R. 2010. “Agency, Values and Well-Being: A Human Development Model.” Social Indicators Research 97: 43-63.

[21] Inghlehart, R., and Welzel, C. 2005. Modernization, Cultural Change and Democracy. New York: Cambridge University Press.

[22] USDA. 2007. "Food Labelling: Food Product Dating.” Fact Sheet United States Department of Agriculture. Accessed August 16, 2010. http://www.fsis.usda.gov/factsheets/food_product_dating/ index.asp.

[23] Foundation for Consumer Protection. 2012. "Food beyond the Date: Often Still in Order.” Media Report May 03, 2012. Accessed December 25, 2014. https://www.konsumentenschutz.ch/medienmitteilungen/ 2012/05/lebensmittel-uber-dem-ablaufdatum-haufig-noch -gut/.

[24] Leimgruber, W. 2010. "The Global Food Crisis: A Crisis in Our Minds? Changes in World-Views and Values to Improve Food Security." In proceedings of the International Conference on Ethics and Professionalism (ICEP) 2010 Sustainable Science, Technology and Society, 24-35.

[25] Food and Agricultural Organization (FAO). 2001. Ethical Issues in Food and Agriculture. Rome: FAO.

[26] Declaration of Nyeleni. 2007. "Nyéléni Declaration in Food Sovereignty.” Journal of Peasant Studies 36 (3): 673-6.

[27] Leimgruber, W. 2008. "Building the Future through Education: The Umthati School Garden Project in the Eastern Cape, South Africa.” In The global Challenge and Marginalization, edited by Valença, M. M., Nel, E., and Leimgruber, W. New York: Nova Science, 133-44.

[28] Victorino, C. J. A. 2000. Cannibals of Nature: Environmental Education, Limits and Qualitiy of Life. Petrópolis: Vozes publisher, 19. (in Portuguese)

[29] Heckman, J. 2007. “A History of Organic FarmingTransitions from Sir Albert Howard's War in the Soil to the USDA National Organic Program.” Accessed August 18, 2010. http://www.westonaprice.org/farming/history-organic-far ming.html.

[30] McDonough, W., and Braungart, M. 1998. "The Next Industrial Revolution.” The Atlantic Magazine, August 18.

[31] European Food Safety Authority (EFSA). 2011. "Feed." Accessed March 2011. 
http://www.efsa.europa.eu/de/topics/topic/feed.htm.

[32] Westendorf, M. L., and Myer, R. O. 2009. "Feeding Food Waste to Swine.” Accessed August 18, 2010. http://edis.ifas.ufl.edu/an143.

[33] Sugiura, K., Yamatani, S., Watahara, M., and Onodera, T. 2009. "Ecofeed, Animal Feed Produced from Recycled Food.” Veterinaria Italiana 45 (3): 397-404.

[34] Food and Agricultural Organization (FAO). 2014. The State of Food Insecurity in the World: Strengthening the Enabling Environment for Food Security and Nutrition. Rome: FAO, 8.

[35] United Nations (UN). 2014. The Millennium Development Goals Report 2014.

[36] Borras, S. M., and Franco, J. C. 2012. “Global Land Grabbing and Trajectories of Agrarian Change: A
Preliminary Analysis.” Journal of Agrarian Change 12 (1): 34-59.

[37] Rulli, M. C., Saviori, A., and D’Odorico, P. 2013. “Global Land and Water Grabbing.” Pro. of the National Academy of Sciences (PNAS) 110 (3): 892-7.

[38] Lazarus, E. D. 2014. "Land Grabbing as a Driver of Environmental Change.” Area 46 (1): 74-82.

[39] Aubert, C. 1996. "Chinese Agriculture, the Limits of Growth.” In Itinéraires Notes et Travaux. Geneva: Institut Universitaire d’Études du Développement (IUED), 3-34.

[40] Van-Vark, C. 2014. "Mining for Smartphone Minerals Is Eating up Farmland.” The Guardian, December 03, 2014.

[41] Leimgruber, W. 2014. Global Change-Global Transformations: Human Processes behind a Dynamic World. Saarbrücken: Scholars’ Press. 